\title{
Serbia on its way to EU membership - the remaining challenges and obstacles
}

\author{
Milenko Petrovic \\ University of Canterbury \\ milenko.petrovic@canterbury.ac.nz
}

Fifteen years after the European Union (EU) promised all the Western Balkan states an EU future by adopting the Thessaloniki agenda in $2003,{ }^{1}$ Croatia is the only Western Balkan state to have succeeded in joining. Although Croatia's journey to EU accession was not quick and smooth (especially when compared with that of its excommunist counterparts from East Central Europe and the Baltics who joined in 2004 and 2007), Serbia and other Western Balkan neighbours of Croatia have had an even harder and (much) bumpier road to the EU. Western Balkan accession had been effectively stalled for several years due to the emergence of enlargement fatigue in the mid-200os. It was briefly re-activated with Croatia's accession and the launch of the so-called Berlin Process in 2014 (Juncos and Whitman, 2015; Petrovic and Wilson 2018; and Mtchedlishvili, 2018 in this Special Issue). However, the accession process stalled again in 2016 and early 2017 with the shock of Brexit and the migration crisis. As of 2018, Western Balkan accession has returned to a prominent place on the EU enlargement agenda.

The first encouraging signs came with the victory of pro-EU parties and candidates in the Dutch parliamentary and French presidential elections in April and May 2017 respectively. The optimism and expectations among the Western Balkan political elites increased after the announcement by European Commission President Junker in his 2017 State of the Union speech (European Commission, 2017) in which he outlines the EU's expectation of enlarguing its membership by 2025. However, the European Commission's Western Balkan Enlargement Strategy issued in February 2018, President Macron's repeated statements that the 'recent enlargement[s] have weakened Europe' (Gray 2018) and even some of Junker's own later 'clarifications' ${ }^{2}$ have considerably cooled this optimism and once again sent mixed signals to the Western Balkan states. Although the basic message of the strategy and the later-issued Commission's progress reports on the Western Balkan candidates and potential candidates for membership have tried to sound 'in line' with Junker's optimistic announcement, the outlined 'circumstances' under which this could happen

\footnotetext{
${ }^{1}$ Adopted by the conclusions of the EU General Affairs and External Relations Council of 16 June 2003 and endorsed in the conclusions (Art. 41) of the European Thessaloniki Council of 19-20 June 2003.

${ }_{2}$ 'The date we are indicating, 2025 is an indication not a promise. We have to know that in the old Europe, the western part of Europe but not only there, there is a kind of enlargement fatigue and this is obviously the case as far as Serbia and Montenegro are concerned' (Juncker, 2018).
} 
can hardly be considered particularly encouraging for the Western Balkan aspirants to EU membership.

Having opened 14 (out of 35) accession negotiations chapters with the EU (by September 2018), Serbia is, after Montenegro, the most advanced towards accession among Western Balkan countries. Realistically, it can hope to close remaining chapters successfully within the next three to four years. However, Serbia together with its Western Balkan counterparts continues to face tougher and more demanding conditions than those which other post-communist candidates for EU membership had faced earlier (see Petrovic, 2017; Mtchedlishvili 2018 in this issue). The above mentioned Commission's Enlargement Strategy of February 2018 has again emphasised the importance and necessity of the fight against corruption in government institutions and spelled out other requirements for the full establishment of the rule of law defined in Chapters 23 and 24. Criteria for their successful completion have already been tightened by the adoption of the so-called 'three pillar approach' to any new enlargement. ${ }^{3}$

The rationale for tightening the accession conditions for the new (i.e. Western Balkan) candidates for EU membership after 2006 and again in the early 2010s through the introduction of the 'three pillar approach' can be questioned (Petrovic, 2017). Yet, the fact is that the level of Serbia's democratisation - and that of its Western Balkan neighbours - is currently significantly below EU standards. The Western Balkan states had made great strides in democratising their political scenes during the time of the EU's 'enlargement enthusiasm,' but there has been little progress since. The Freedom House's Nation in Transit Democracy scores have not improved in all the countries of the region. On the contrary, they stagnated, and even worsened in recent years (Table 1) (see also Kovacevic 2018 in this Issue). Although the Transparency International's Corruption Perception Index (TICPI) shows more encouraging trends, Serbia, together with other Western Balkan states, still demonstrates significantly lower levels than those achieved in the post-communist states which joined the EU in 2004, according to both indicators of democratisation shown in Table 1.4 It is clear that authoritarian trends have been a global phenomenon since the outbreak of the global economic crisis in 2008/09.5 Post-communist states like Poland, Slovakia and, particularly, Hungary which were considered well-consolidated democracies 6 have decreased their democracy scores over the last several years (Table 1). This may make Serbia's faltering

\footnotetext{
3 Throughout the period 2012-2014 the European Commission classified the most important and most demanding (basic) accession conditions as the 'three pillars': the rule of law, economic governance and public administration reform [which] "the Commission has put particular emphasis on" (European Commission, 2014, p.1.).

4 Similar comparative results can be obtained from other international organisations or projects specialising in monitoring and assessing democratisation, marketisation and human rights and political and civil liberties protection around the world (such as the Global Ranking Association, the Varieties of Democracy project, etc). The papers included in this issue rely on the Freedom House's Nations in Transit (NIT) 'democracy scores' and the Transparency International's Corruption Perception Index (TICPI). Although it is already included in the NIT's (average) 'democracy score' (which looks at the state of play of political rights, civil liberties, corruption, the rule of law, media, civil society and the electoral process), the level of corruption in the respective countries as measured by the TICPI is also used as a separate indicator -- in order to address the importance of this factor of democratisation, which is often used as an expression of not only the existing level of corruption in the public sector but also of the general stability of democratic institutions and the rule of law in the respective countries.

5 The Journal of Democracy has devoted two of its issues in 2015 to this topic (2015a and 2015b) while the Freedom House's Nations in Transit issue of June 2015 was entitled: 'Democracy on the Defensive in Europe and Eurasia' and the title of its publication Freedom in the World issued in 2018 was 'Democracy in Crisis'.

${ }^{6}$ According to the Freedom House's NIT methodology, the average democracy scores (shown here in Table 1) classify the assessed countries into one of the following groups: from 1 to 2.99 - Consolidated Democracies, from 3 to 3.99 - Semi-Consolidated Democracies; from 4 to 4.99 - Transitional or Hybrid regimes, from 5 to 5.99 SemiConsolidated Authoritarian Regimes and from 6 to 7 - Consolidated Authoritarian Regimes.
} 
internal democratisation less surprising yet no less challenging with regards to its EU accession bid. The necessity to further consolidate the functioning of the country's democratic institutions, principally through fighting corruption and establishing the rule of law, remains of paramount importance for the successful closure of Serbia's accession negotiations.

Table 1. Indicators of post-communist democratisation and marketisation

\begin{tabular}{|l|c|c|c|c|c|c|c|c|}
\hline & \multicolumn{4}{|l|}{ Democracy score* } & \multicolumn{4}{c|}{ TICPI**** } \\
\hline & $\mathbf{1 9 9 9}$ & $\mathbf{2 0 0 6}$ & $\mathbf{2 0 1 2}$ & $\mathbf{2 0 1 7}$ & $\mathbf{1 9 9 9}$ & $\mathbf{2 0 0 6}$ & $\mathbf{2 0 1 2}$ & $\mathbf{2 0 1 7}$ \\
\hline Hungary & $\mathbf{1 . 8 8}$ & $\mathbf{2 . 1 4}$ & $\mathbf{2 . 8 9}$ & $\mathbf{3 . 5 4}$ & $\mathbf{5 2}$ & $\mathbf{5 2}$ & $\mathbf{5 1}$ & $\mathbf{4 5}$ \\
\hline Poland & $\mathbf{1 . 5 8}$ & $\mathbf{2 . 3 6}$ & $\mathbf{2 . 1 8}$ & $\mathbf{2 . 5 7}$ & $\mathbf{4 2}$ & $\mathbf{3 7}$ & $\mathbf{5 8}$ & $\mathbf{6 0}$ \\
\hline Slovakia & $\mathbf{2 . 7 1}$ & $\mathbf{2 . 1 4}$ & $\mathbf{2 . 5 7}$ & $\mathbf{2 . 6 1}$ & $\mathbf{3 7}$ & $\mathbf{4 7}$ & $\mathbf{4 6}$ & $\mathbf{5 0}$ \\
\hline Latvia & $\mathbf{2 . 2 9}$ & $\mathbf{2 . 0 7}$ & $\mathbf{2 . 0 7}$ & $\mathbf{2 . 0 4}$ & $\mathbf{3 4}$ & $\mathbf{4 7}$ & $\mathbf{4 9}$ & $\mathbf{5 8}$ \\
\hline Lithuania & $\mathbf{2 . 2 9}$ & $\mathbf{2 . 2 9}$ & $\mathbf{2 . 3 2}$ & $\mathbf{2 . 3 2}$ & $\mathbf{3 8}$ & $\mathbf{4 8}$ & $\mathbf{5 4}$ & $\mathbf{5 9}$ \\
\hline Romania & 3.54 & 3.29 & 3.50 & 3.39 & 33 & 31 & 44 & 48 \\
\hline Bulgaria & 3.58 & 2.89 & 3.18 & 3.36 & 33 & 40 & 41 & 43 \\
\hline Croatia & 4.46 & 3.75 & 3.61 & 3.71 & 27 & 34 & 46 & 49 \\
\hline Maced FYR & 3.83 & 3.82 & 3.93 & 4.43 & 33 & 27 & 43 & 35 \\
\hline Albania & 4.75 & 3.82 & 4.25 & 4.14 & 23 & 26 & 33 & 38 \\
\hline Bosnia-Hrz & 5.42 & 4.04 & 4.39 & 4.54 & N/A & 29 & 42 & 38 \\
\hline Montenegro & 5.50 & 3.93 & 3.82 & 3.89 & N/A & N/A & 41 & 46 \\
\hline Serbia & $\mathbf{5 . 5 0}$ & $\mathbf{3 . 6 8}$ & $\mathbf{3 . 6 4}$ & $\mathbf{3 . 8 2}$ & $\mathbf{2 4}$ & $\mathbf{2 7}$ & $\mathbf{3 9}$ & $\mathbf{4 1}$ \\
\hline
\end{tabular}

Sources: Freedom House, Nations in Transit; Transparency International, Corruption Perception Index (various years; see footnote 3 ).

While the European Commission's repeated insistence on further democratisation and the tightened criteria for closing Chapters 23 and 24 are demanding, there is now an additional accession condition specified in the February strategy for all the Western Balkan membership candidates. This is a requirement for the countries to solve all their 'bilateral disputes ... as a matter of urgency' (European Commission 2018, p.7). This seems to pose a particularly challenging task for the regional political elites. While Montenegro hopes to solve its only remaining (though nearly 30 year-old) dispute with Croatia over the sea border relatively soon, Serbia and most of the remaining four Western Balkan states (Albania, Bosnia and Herzegovina, Kosovo, and Macedonia) have many more (and more serious) problems to resolve with their neighbours. Serbia will also have to meet a particularly challenging additional accession criterion (incorporated in negotiations of Chapter 35), which none of the previous candidates for EU membership had to meet: to 'normalise' relations with its former province of Kosovo, which unilaterally declared its independence in 2008. In accordance with the above-mentioned condition on the 'urgent' resolution of bilateral regional disputes in the Commission's February strategy, Serbia, as stated in the Commission's report on Serbia's progress (European Commission, 2018a), is expected to sign a 'legally binding agreement' which will guarantee 'the full normalisation of [Serbia's] relations with Kosovo' (ibid, 4). This seems to be an extremely tough stipulation for the Serbian government, considering its staunch refusal to accept Kosovo's independence and the level of mistrust between it and the Kosovo government. However, thanks to EU assistance and the commitment of interested parties, the Kosovo 'knot' may in fact pose 
(as discussed by Petrovic and Wilson 2018 in this issue) less of a problem for Serbia's accession than the issues that it has with some other neighbours, particularly Croatia.

\section{Structure of the Special Issue}

This special issue of ANZJES features five articles written by scholars from New Zealand, Australia and Serbia (most of whom were born in Serbia). The contributions discuss the afore-mentioned challenges and obstacles Serbia has to overcome on its way to EU membership. The special issue begins with Maja Kovačević's article which addresses the stalled progress of (further) consolidation of institutions of democracy in Serbia over the last several years in the context of the EU's 'StabilisationDemocratisation Dilemma' approach to political developments in the Western Balkans. Arguing that the EU has prioritised 'effective government rather than democratic governance' for a long time - thus helping legitimise authoritarian rulers and 'oligarchisation' in the region - Kovačević expects that the EU will continue to take such an approach. She identifies the main reason for it - a number of security challenges and risks in the Western Balkans which pose a threat to the EU's internal security. Among these, Kovačevic emphasises the importance of the regional connections with international terrorism, organised crime and irregular migration in particular. The final section of the paper discusses the Serbian government's capacity in the areas of judiciary, justice, freedom and security as defined in the prism of the EU's criteria for negotiations in Chapters 23 and 24. Perhaps not surprisingly, the author concludes that the European Commission has given a positive assessment of Serbia's performances in dealing with the 2015 migrant crisis and to the related successful fight against human trafficking. Less so to judicial independence or the fight against corruption.

The role of pro-reform and pro-EU civil society in Serbia's democratisation and accession to the EU is examined in Nina Markovic's contribution. The article critically assesses the origins of civil society activism in Serbia during Milosevic's authoritarianism in the 1990s, its role in overthrowing Milosevic's regime in 2000, and activities of civil society organisations and actors in post-Milosevic Serbia. After elaborating how pro-reform and pro-EU civil society 'maintained oppositional political discourses' against the Milosevic regime and subsequently played a pivotal role in overthrowing it, the author identifies several major areas of activities of pro-reform civil society actors and organisations in post-Milosevic Serbia. She analyses the character and scope of these activities in the form of short case studies in the second part of the article and highlights the importance of those civil activities which serve as the watchdog of democratisation and promotion/advocacy of the EU and Serbia's accession. These also include the necessity of meeting the accession conditions such as good neighbourly relations and regional cooperation. Markovic emphasises the active role of pro-reform civil society in Serbia in fighting the deterioration of media freedom in recent years and concludes that '[v]iable, protected and independent civil society is vitally important' for the successful continuation of Serbia's accession to the EU.

Milenko Petrovic and Garth Wilson's contribution looks at Serbia's capacity to successfully meet the EU's accession conditions regarding the resolution of regional bilateral disputes and the 'normalisation' of its relations with Kosovo as stressed in the 2018 Commission's Enlargement strategy and its report on Serbia (European Commission, 2018 and European Commission 2018a). After providing a critical overview of the origins and recent developments of Serbia's problematic relations with 
Kosovo and its three neighbours to the west - Croatia, Bosnia and Herzegovina, and Montenegro - the authors argue that the resolution of the 'Kosovo knot' remains 'crucial for the successful completion of its accession to the EU' but that problems in Serbia's relations with its three western neighbours might also pose serious obstacles to its accession bid. Moreover, they conclude that thanks to EU assistance and a strong interest by both parties to come closer to a 'binding agreement', the Kosovo issue may, in fact, be less challenging for Serbia's accession than a number of open issues which currently trouble its relations with Croatia.

The contribution by Bozo Drasković, Mihailo Djukić and Malisa Djukić addresses a specific aspect of Serbia's accession process, which refers to liberalisation of the transfer of property rights over natural resources, particularly agricultural land. The authors argue that although the EU regulations do not specifically require the membership countries to fully liberalise their agricultural land markets, Serbia as a candidate country is (still) expected to liberalise trade with agricultural land in order to successfully negotiate (and close) accession negotiations, i.e. Chapter 4 (free movement of capital) and Chapter 11 (Agriculture). In addition, according to the Stabilisation and Association Agreement which it signed with the EU in 2008, Serbia was required to complete full liberalisation of trade with agricultural land by September 2017. However, the Serbian government avoided to do it. The authors conclude that the Serbian government should continue with the same approach and, following the examples of post-communist countries which joined the EU earlier, find a way to avoid full liberalisation of its agricultural land market for several reasons which they extensively discuss in the paper. The most compelling one is related to the affordability of agricultural land to small domestic farmers who dominate Serbia's land ownership structure and would not be able to withstand the strong international competition.

The issue ends with an article and a book review written by two $\mathrm{PhD}$ candidates, Daviti Mtchedlishvili and Xiwen Wang respectively. In his article, Mtchedlishvili critically discusses the bumpy road of the Western Balkan states towards EU accession from the early 2000 s to the present day. He highlights the tougher and more variable nature of the accession conditions that these states are required to meet in comparison to the post-communist states which joined the EU in 2004 and 2007. The author concludes that 'one of the most important catalysts [of the slow advance in the accession of the Western Balkan states] lies in the inconsistency and vagueness of the EU approach to the accession of the [se]... states'.

Wang reviews a recently published edited volume which assesses a quarter century of democratisation and economic marketisation of post-communist countries in the Eurasia region. The volume comprises contributions which also looked at developments in the Western Balkans and Serbia.

\section{Bibliography}

Bieber, Florian (2018). It is time to ditch the Berlin Proces. European Western Balkans, 10 July, (available at: https://europeanwesternbalkans.com/-2018/o7/10/time-ditchberlin-process/). 
European Commission (2017). President Jean-Claude Juncker's State of the Union Address 2017, Brussels, 13 September (available at: http://europa.eu/rapid/pressrelease_SPEECH-17-3165_en.htm.

European Commission (2014). Enlargement Strategy and Main Challenges 2014-15. COM (2014) 700 final, Brussels 8.10.2014.

European Commission (2018a). A credible enlargement perspective for and enhanced EU engagement with the Western Balkans. COM (2018) 65 final, Strasbourg, 6.2.2018.

European Commission (2018b). Serbia 2018 Report. COM (2018) 450 final, Strasbourg, 17.4.2018.

Freedom House (2018). Democracy in Crisis. Freedom in the World (available at; https://freedomhouse.org/report/freedom-world/freedom-world-2018).

Freedom House (various years), Nations in Transit. (available at: https://freedomhouse.org/report-types/nations-transit).

Journal of Democracy (2015a), The Authoritarian Resurgence (26) 2, April 2015.

Journal of Democracy (2015b), Authoritarianism Goes Globally (26) 4, October 2015.

Juncos, Anna and Richard Whitman (2015). Europe as a Regional Actor: Neighbourhood Lost. Journal of Common Market Studies (53) S1, pp. 200-215.

Juncker, Jean-Claude (2018), Interview to Euronews: Jean-Claude Juncker and EU 'enlargement fatigue', Euronews, 02/03/2018 (available at: https://www.euronews.com-/2018/03/02/jean-claude-juncker-and-eu-enlargement-fatigue).

Gray, Andrew (2018). Macron pours cold water on Balkan EU membership hopes. Politico, 5/17/18. Available at: https://www.politico.eu/article/emmanuel-macronpours-cold-water-balkans-eu-membership-enlargement/.

Petrovic, Milenko (2017). Post-Communist Transition under the Umbrella of Uneven Europeanisation: East Central Europe, the Baltic States and the Balkans. In Fish, Steven, M., Gill, Graeme and Milenko Petrovic (eds.). A Quarter Century of PostCommunism Assessed, Palgrave Macmillan, pp. 41-74.

Transparency International (various years), Corruption Perception Index. Available at: https://www.transparency.org/research/cpi/overview. 